\title{
Manajemen Pengembangan Potensi Pariwisata Daerah Di Desa Wisata Okura Kota Pekanbaru Provinsi Riau
}

\author{
Robby Kurniawan Junaidy ${ }^{\text {1) }}$, Sri Suwitri ${ }^{2)}$, Kismartini ${ }^{3)}$, \\ Magister Ilmu AdministrasinFakultas Ilmu Sosial dan Ilmu Politik Universitas Diponegoro \\ Email : fisip@undip.ac.id ${ }^{1}$
}

ARTICLE INFO

Keywords:

Management,

Tourism Development, Okura Tourism Village

\section{ABSTRACT}

Tourism is one of the development sectors that received government attention to continue to be developed until now, because this sector is considered quite potential for the development of people's economy. The problem is that the number of foreign tourists who enter the city of Pekanbaru tend to decrease in 2011-2016. The lack of tourist attractions in Pekanbaru especially nature tourism, forcing the government of Pekanbaru City to think of new and interesting sights worth developing. The purpose of this study is to identify the potential and condition of tourism, analyzing Planning, Organizing, Actuating and Controlling, and analyzing the supporting and inhibiting factors from the development of regional tourism potential in the Okura Village of Pekanbaru City of Riau Province. The method to be used is qualitative descriptive research. Management of tourism development potential of the region in the Village Tourism Okura Pekanbaru Riau Province has not run optimally. We can see from the lack of supporting infrastructure, resources and finance also become obstacles. And the absence of participation of stakeholders or other tourism developers in Pekanbaru. The recommendation of this research is to provide special fund to focus on development in Okura Tourism Village. Empowering human resources in Okura Tourism Village by providing various coaching and training, upcoming experts to provide special knowledge to the community in Okura Village. Increase cooperation with private parties or parties that would help the development of Okura Tourism Village so that it can create good coordination between the parties.

\section{PENDAHULUAN}

\section{Latar Belakang}

Pariwisata merupakan salah satu sektor pembangunan yang mendapat perhatian pemerintah untuk terus dikembangkan sampai saat ini, karena sektor ini dinilai cukup berpotensi bagi perkembangan perekonomian rakyat. Potensi ini didasarkan atas beberapa faktor pendukung seperti geografis dan keindahan alam serta kekhasan sosial budaya masyarakat Indonesia sebagai daya tarik utama dalam pengembangan sektor wisata.

Menurut Undang-Undang Nomor 33 tahun 2004 tentang Perimbangan Keuangan antara Pusat dan Daerah pasal 1 angka 18 dikatakan Pendapatan Asli Daerah, selanjutnya disebut PAD, adalah pendapatan yang diperoleh daerah yang dipungut berdasarkan peraturan daerah sesuai dengan peraturan perundangundangan.Secara ekonomi sektor ini memiliki jaringan ke depan (forward linkage) yang luas apabila dikembangkan, karena akan dapat menumbuhkan industri pariwisata serta dampaknya bagi pembangunan ekonomi masyarakat yang melibatkan cukup banyak tenaga kerja dan berorientasi global.

Indonesia memiliki daerah dengan beragam potensi di bidang kepariwisataan yang kemudian masing-masing daerah tersebut semakin berbenah diri untuk mengembangkan sektor pariwisatanya, begitu juga dengan daerah Kota Pekanbaru Provinsi Riau. Sesuai dengan kebijakan Peraturan Daerah nomor 13 tahun 2000 tentang Promosi Pariwisata Daerah Kota Pekanbaru bahwa pengembangan pariwisata adalah salah satu urusan yang diserahkan Pemerintah Provinsi Riau kepada Pemerintah Kota Pekanbaru untuk melakukan promosi pariwisatanya.

Pariwisata berbasis budaya melayu atau kearifan lokal adalah prioritas utama dalam promosi yang dilakukan untuk menggenjot jumlah wisatawan datang ke Kota Pekanbaru dan potensi pengembangan objek 
pariwisata berbasis budaya melayu tidak dimiliki oleh daerah lain. Berikut adalah data jumlah wisatawan mancanegara yang masuk ke Kota Pekanbaru :

Tabel 1.1

Perbandingan Jumlah Wisatawan Mancanegara Yang Masuk Ke Kota Pekanbaru Tahun 2011 - 2016

\begin{tabular}{|c|c|c|c|c|}
\hline .No & TAHUN & $\begin{array}{c}\text { JUMLAH } \\
\text { TOTAL }\end{array}$ & $\begin{array}{c}\text { SELISIH } \\
(+/-)\end{array}$ & $\begin{array}{c}\text { PERSENT } \\
\text { ASE }\end{array}$ \\
\hline 1. & 2011 & 25.227 & - (162) & \multirow{2}{*}{$\begin{array}{c}-0,64 \% \\
(2011- \\
2012) \\
+3,53 \% \\
(2012- \\
2013)\end{array}$} \\
\hline 2. & 2012 & 25.065 & $+(884)$ & \\
\hline 3. & 2013 & 25.949 & - (192) & \multirow[t]{2}{*}{$\begin{array}{c}-0,74 \% \\
(2013- \\
2014)\end{array}$} \\
\hline 4. & 2014 & 25.757 & $-(32)$ & \\
\hline 5. & 2015 & 25.725 & \multirow[t]{2}{*}{$-(821)$} & \multirow{2}{*}{$\begin{array}{c}-3,19 \% \\
(2015- \\
2016)\end{array}$} \\
\hline 6. & 2016 & 24.904 & & \\
\hline
\end{tabular}

Sumber : Kantor Imigrasi Kelas I Pekanbaru

Diolah Oleh : Dinas Kebudayaan Dan Pariwisata Kota Pekanbaru

Tabel 1.1 jumlah Wisatawan Mancanegara yang masuk ke Kota Pekanbaru pada tahun 2011-2012 mengalami penurunan sejumlah 162 jiwa dan mengalami peningkatan, yaitu tahun 2012 - 2013 sejumlah 884 jiwa kemudian pada tahun 2013-2014 mengalami penurunan sejumlah 192 jiwa selanjutnya pada tahun 2014-2015 mengalami penurunan 32 jiwa kemudian pada tahun 2015-2016 kembali mengalami penurunan sejumlah 821 jiwa. Analisis peneliti sejauh ini selisih perbandingan antara penurunan dengan peningkatan yaitu 4 berbanding 1 , menurut pengamatan peneliti penyebab cenderungnya terjadi penurunan jumlah wisatawan disebabkan oleh kurangnya informasi wisata terbaru yang tersedia di Kota Pekanbaru serta kurangnya promosi dari pihak Pemerintah Kota Pekanbaru. 
Minimnya tempat wisata di Pekanbaru khususnya wisata alam, memaksa pemerintah Kota Pekanbaru untuk memikirkan tempat wisata baru dan menarik yang layak dikembangkan, oleh karena itu Pemerintah Kota Pekanbaru melalui Walikota Pekanbaru Firdaus menetapkan Kelurahan Okura, Kecamatan Rumbai Pesisir sebagai destinasi wisata baru di Kota Pekanbaru yaitu disebut Desa Wisata Okura.

Desa Wisata Okura adalah salah satu desa yang ada di Kota Pekanbaru yang dikembangkan oleh Pemerintah Kota Pekanbaru untuk menjadi desa wisata, desa ini masih tradisional yang mempunyai ciri khas budaya asli melayu sehingga menarik wisatawan untuk mengunjungi Kota Pekanbaru. Dipilihnya desa okura sebagai tempat wisata tidak terlepas dari lokasi desa ini yang berada di pinggir Kota Pekanbaru yang berbatasan dengan beberapa Kabupaten di Provinsi Riau.

\section{Tujuan}

1. Mengidentfikasikan potensi dan kondisi pariwisata daerah di Desa Wisata Okura Kota Pekanbaru Provinsi Riau.

2. Menganalisis Planning, Organizing, Actuating dan Controlling dalam pengembangan potensi pariwisata daerah di Desa Wisata Okura Kota Pekanbaru Provinsi Riau.

3. Menganalisis apa saja yang menjadi faktor pendukung dan penghambat dari pengembangan potensi pariwisata daerah di Desa Wisata Okura Kota Pekanbaru Provinsi Riau.

\section{LANDASAN TEORI}

Manajemen Publik merupakan bagian yang sangat penting dalam sistem Administrasi Publik. Manajemen meruapakan mesin penggerak administrasi publik dan diartikan bahwa manajemen adalah integrasi dari perencanaan, pengorganisasian, pelaksanaan atau penggerakan dan pengawasan / evaluasi.

Pada dasarnya manajemen publik, yaitu manajemen instansi pemerintah. Overman dalam Pasolong (2011:83), mengemukakan bahwa manajemen publik bukanlah "scientific management", meskipun sangat dipengaruhi oleh "scientific management". Managemen publik bukanlah "policy analysis", bukanlah juga administrasi publik, merefleksikan tekanan-tekanan antara orientasi "rational-instrumental" pada satu pihak, dan orientasi politik kebijakan pihak lain. Manajemen publik adalah suatu studi interdisipliner dari aspekaspek umum organisasi, dan merupakan gabungan antara fungsi manajemen seperti planning, organizing dan controlling satu sisi, dengan SDM, keuangan, fisik, informasi, dan politik. Berdasarkan pendapat overman tersebut, OTT, Hyde dan Shafritz dalam pasolong (2011:83), mengemukakan bahwa manajemen publik dan kebijakan publik merupakan dua bidang administrasi publik merepresentasikan sistem jantung dan sirkulasi dalam tubuh manusia. Dengan kata manajemen publik merupakan proses mengerakkan SDM dan non SDM sesuai perintah kebijakan publik.

6 sumber daya pokok manajemen menurut George Robert Terry :

1. Man (Human Resources), dalam manajemen publik,sumber daya manusia ini tidak hanya mampu, tetapi harus memenuhi persyaratan karier.

2. Money (finances), dalam manajemen publik, money sangat terkait dengan ketentuan peruntukan dari mata anggaran yang lebih disetujui terlebih dahulu.

3. Material (logistik),

4. Machine (information), manajemen publik dikelola melalui informasi yang berbentuk persuratan dan alat komunikasi lain serta dokumentasi dan arsip.

5. Methods (legitimate), keabsahan atau legitimasi suatu kebijakan juga sangat penting. Dalam manejemen publik dikenal dengan persetujuan atasan atau sesuai dengan peraturan perundang-undanganyang berlaku.

6. Market (participation), partisipasi dapat berbentuk dukungan dapat pula berupa penolakan. Keduanya merupakan masukan uang diperlukan dalam proses dan implementasi kebijakan publik. Dikenal ada dua bentuk partisipasi: pertama murni yang muncul secara spontan dari rakyat, kedua mobilisasi yaitu partisipasi yang diorganisasi oleh pihak tertentu.

J. Steven Ott, Albert C. Hyde dan jay M. Shafritz dalam Pasolong (2011:83), berpendapat bahwa dalam tahun 1990an, manajemen publik mengalami masa transisi dengan beberapa isu terpenting yang akan sangat menantang, yaitu: 1) Privatisasi sebagai suatu alternatif bagi pemerintah dalam memberikan pelayanan publik, 2) Rasionalitas akuntabilitas, 3) Perencanaan dan kontrol, 4) Keuangan dan penganggaran 
dan 5) Produktifitas sumber daya manusia. Isu-isu ini telah menantang sekolah atau perguruan tinggi yang mengajarkan manajemen publik atau administrasi publik untuk menghasilkan calon manajer publik profesional yang kualitas tinggi, dan penataan sistem manajemen yang lebih baik.

Pengembangan manajemen publik dimasa mendatang, menurut "the national commission on public Service" di Amerika serikat lihat Ott, Hyde dan Shafritz dalam Pasolong (2011:84), perlu memperhatikan beberapa hal, yaitu: 1) perlu mengidentifikasi secara jelas peran dari pelayan publik dalam proses demokratis, sekaligus standar etika dan kinerja yang tinggi dari para pejabat kunci; 2) perlu fleksibilitas dalam menata organisasi, termasuk kebebasan mempekerjakan dan memecat pegawai yang harus diberikan kepada para tinggin kabinet dan pimpinan instansi; 3) pengangkatan atau penunjukan pejabat oleh presiden harus dikurangi, dan lebih diberikan ruang pengembangan karir profesional, dan 4) pemerintah harus melakukan investasi lebih besar dibanding pendidikan dan pelatihan eksekutif dan manajemen.

Perkembangan manajemen publik paling tidak dipengaruhi beberapa pandangan yaitu manajemen normatif, manajemen deskriptif, manajemen stratejik dan manajemen publik. Manajemen normatif menggambarkan apa sebaiknya dilakukan oleh seorang manajer dalam proses manajemen, sedangkan manajemen diskriptif menggambarkan apa yang kenyataannya yang dilakukan oleh manajer ketika menjalankan tugasnya Chung dan Megginson dalam Pasolong (2011:84). Kedua pandangan ini tidak menentukan locus yang pasti, karena itu manajemen yang dimaksudkan adalah manajemen umum. Manajemen stratejik menggambarkan suatu cara memimpin organisasi untuk mencapai misi, tujuan dan sasaran. Sedangkan pandangan manajemen publik menggambarkan apa yang sebaiknya dilakukan dan senyatanya pernah dilakukan oleh para manajer publik di instansi pemerintah. Selanjutnya manajemen kinerja menggambarkan bagaimana merancang untuk meningkatkan kinerja organisasi.

\section{METODE PENELITIAN}

Penelitian dengan metode kualitatif dan jenis deskriptif bertujuan untuk memberikan gambaran mengenai latar dan interaksi yang kompleks dari partisipan serta fenomena- fenomena menurut pandangan dan definisi partisipan. Penelitian metode kualitatif dan jenis deskriptif merupakan penelitian yang dimaksudkan untuk mengumpulkan informasi mengenai status fenomena, gejala atau keadaan yang ada, yaitu keadaan gejala menurut apa adanya pada saat penelitian dilaksanakan.

Fokus penelitian dalam penelitian ini adalah menggali informasi mendalam dengan mengamati, menganalisis Manajemen Pengembangan Potensi Pariwisata Daerah Di Desa Wisata Okura Kota Pekanbaru Provinsi Riau Dalam penelitian ini diambil situs di Dinas Kebudayaan dan Pariwisata Kota Pekanbaru dan di Desa Wisata Kelurahan Tebing Tinggi Okura Kecamatan Rumbai Pesisir serta pihak-pihak dan instansi yang tekait dalam situs penelitian.

\section{PEMBAHASAN}

\section{Potensi dan kondisi pariwisata daerah di Desa Wisata Okura Kota Pekanbaru Provinsi Riau}

Desa Wisata Okura menyediakan pemandangan alam berupa perkebunan dan hutan bakau yang asik untuk ditelusuri oleh wisatawan serta dinikmati diatas kapal pada saat perjalanan menuju Desa Wisata Okura. Selain hutan bakau Desa Wisata Okura memiliki masyarakat yang menggunakan bahasa asli melayu, kegiatan berkuda, memanah, menganyam, dan tarian tradisional untuk menyambut tamu, hamparan perkebunan milik masyarakat yang masih asri. Semua kegiatan yang dilakukan oleh masyarakat Desa Wisata Okura sesuai dengan budaya melayu yang hidup dalam masyarakat Desa Okura.

Pengembangan Desa Wisata Okura yang berbasis wisata alam dan kearifan lokal hendaknya memelihara keaslian lingkungan tanpa merusak alam yang ada di Desa Wisata Okura karena produk yang ditawarkan pada wisatawan berbentuk budaya tradisional masyarakat melayu dan keaslian alam yang ada di Desa Wisata Okura. Terjaganya kelestarian budaya melayu dan alam yang ada di Desa Wisata Okura menjadi sangat penting seperti kegiatan masyarakat, rumah adat panggung dan makanan khas melayu yang ada di Desa Okura.karena unsur-unsur keaslian yang ada di Desa Wisata Okura menjadi daya tarik yang berbeda dengan desa-desa atau tempat-tempat yang lain. Seperti terlihat pada gambar 4.3.1.1 : 
Gambar 4.3.1.1

Rumah Adat Panggung Melayu di Desa Okura

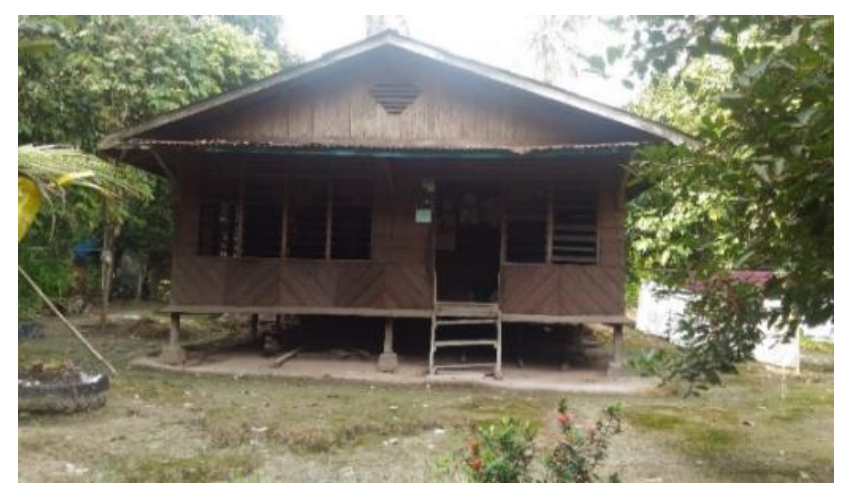

Sumber: Dokumentasi Peneliti

Masyarakat Desa Okura mengharapkan agar Pemerintah memperhatikan betul kebutuhan wisatawan yang berkunjung ke Desa Wisata Okura terutama penyediaan tempat seni pertunjukan khas melayu, peragaan pembuatan barang-barang kerajinan, tempat parkir, kantor pengelola dan kamar kecil (WC umum). Belum adanya kondisi yang mendukung kegiatan wisatawan menjadikan Desa Wisata Okura kurang diminati oleh wisatawan lokal dan mancanegara karena tidak sesuai dengan harapan pengunjung, untuk menikmati seni pertunjukan khas melayu, belum adanya tempat penjualan sovenir dan oleh-oleh serta kamar kecil.

Kebutuhan wisatawan yang berkunjung belum terpenuhi karena keterbatasan dana yang dipersiapkan oleh Pemerintah Kota Pekanbaru untuk pengembangan Desa Wisata Okura. Pemerintah Kota Pekanbaru tidak memiliki anggaran yang cukup dan kesulitan untuk mencari atau melobi pihak swasta agar mau mengembangkan Desa Wisata Okura. Pemerintah masih menggunakan dana PNPM untuk mengelola dan mengembangkan Desa Wisata Okura. berikut:

Adapun kondisi Kondisi yang diharapkan oleh Wisatawan yang berkunjung di Desa Okura sebagai

1. Adanya Penginapan untuk wisatawan

2. Adanya kamar mandi dan WC

3. Adanya Air bersih yang layak di konsumsi

4. Adanya tempat sampah

5. Adanya toko cendaramata/ sovenir

6. Adanya bank dan money changer / penukaran mata uang.

Kondisi yang diharapkan wisatawan tentu sangat wajar karena hal tersebut sangat penunjang kegiatan pariwisata yang ada di Desa Wisata Okura. Wisatawan lokal maupun mancanegara tentu melihat apa saja keadaan yang menarik dan nyaman sehingga menimbulkan rasa senang ketika berkunjung ke Desa Wisata Okura. Dengan adanya kondisi yang diharapkan maka kemungkinan besar Desa Wisata Okura akan lebih maju dan pengunjung akan berkunjung kembali ke Desa Wisata Okura.

Dari hasil analisis dan data yang diperoleh peneliti dapat disimpulkan bahwa pengembangan Desa Wisata Okura dengan melihat kondisinya yang menjadi Desa Wisata alam yang berbasis tradisional, menonjolkan alam berupa hutan bakau dipinggir sungai siak, kegiatan masyarakat memanah, berkuda, menganyam serta rumah adat melayu, menjadi daya tarik yang unik untuk menarik wisatawan lokal dan mancanegara untuk berkunjung ke Desa Wisata Okura. Pengembangan Desa Wisata Okura masih sepenuhnya tanggungjawab Pemerintah Kota Pekanbaru melalui Dinas Kebudayaan dan Pariwisata Kota Pekanbaru. Belum adanya kerjasama Pemerintah dengan pihak swata menjadikan pengembangan Desa Wisata Okura sepenuhnya berharap pada dana PNPM yang disediakan oleh Pemerintah Kota Pekanbaru.

Manajemen pengembangan potensi pariwisata di Desa Wisata Okura Kota Pekanbaru Provinsi Riau di analisis melalui teori Planning, Organizing, Actuating, Controlling George Robert Terry :

\section{Perencanaan pengembangan potensi pariwisata di Desa Wisata Okura Kota Pekanbaru Provinsi Riau.}


Perencanaan merupakan proses terpenting dari semua fungsi manajemen karena tanpa perencanaan fungsi-fungsi lain pengorganisasian, penggerakkan, pengendalian tak dapat berjalan.

\section{1) Tujuan, sasaran, visi dan misi didasarkan pada kearifan local}

Penetapan visi dan misi Dinas Kebudayaan dan Pariwisata Kota Pekanbaru disesuaikan dengan adat istiadat kebudayaan melayu yang dimiliki. Kebudayaan melayu menjadi andalan Pemerintah Kota Pekanbaru yang kemudian perlu dikelola dengan baik dan dikembangkan sebagai objek wisata andalan dan menjadikan ciri khas Kota Pekanbaru. Sesuai dengan Visi Misi Dinas Kebudayaan dan Pariwisata Kota Pekanbaru.

Dengan adanya rencana melalui visi dan misi atau tujuan yang ingin dicapai melalui aturan formal, tentunya sebagai landasan bagi Dinas Kebudayaan dan Pariwisata Kota Pekanbaru untuk melaksanakan pengembangan Desa Wisata Okura yang berbasis kearifan lokal. Perencanaan pengembangan Desa Wisata Okura hanya tertulis dalam bentuk visi dan misi dari Dinas kebudayaan dan Pariwisata Kota Pekanbaru. Belum adanya program khusus Pengembangan Desa Wisata Okura agar berdampak positif dan berkelanjutan, menyebabkan perencanaan yang dilakukan oleh Dinas kebudayaan dan Pariwisata Kota Pekanbaru belum optimal dan berdampak positif.

\section{2) Pendataan segala informasi dan sumber daya yang basis pengelolaan Desa Wisata Okura}

Pemetaan potensi sumberdaya dan wisata yang dilakukan oleh Dinas Kebudayaan dan Pariwisata pada Desa Wisata Okura diketahui bahwa, Desa Wisata Okura memiliki potensi wisata yang berbasis wisata alam dan budaya melayu. Dinas Kebudayaan dan Pariwisata Kota Pekanbaru menilai potensi wisata Desa Okura perlu dikembangkan dengan menyediakan program yang cocok dengan potensi Desa Wisata Okura dan dilaksanakan secara berkelanjutan agar memperoleh manfaat dalam menarik minat wisatawan untuk berkunjung ke Desa Okura.

Pemetaan potensi sumberdaya dan wisata yang dilakukan oleh Dinas Kebudayaan dan Pariwisata pada Desa Wisata Okura diketahui bahwa, Desa Wisata Okura memiliki potensi wisata yang berbasis wisata alam dan budaya melayu. Dinas Kebudayaan dan Pariwisata Kota Pekanbaru menilai potensi wisata Desa Okura perlu dikembangkan dengan menyediakan program yang cocok dengan potensi Desa Wisata Okura dan dilaksanakan secara berkelanjutan agar memperoleh manfaat dalam menarik minat wisatawan untuk berkunjung ke Desa Okura.

3) Pengidentifikasian para pemangku kepentingan yang menjadi mitra pengelolaan Desa Wisata Okura

Pengidentifikasian pemangku kepentingan oleh Dinas Kebudayaan dan Pariwisata Kota Pekanbaru perlu dikakukan. Hal tersebut agar pengelolaan dan pengembangan Desa Wisata Okura berjalan dengan baik. Sehingga mampu menarik minat wisatawan lokal dan mancanegara untuk berkunjung ke Desa Wisata Okura.

Promo pariwisata selama ini hanya dibebankan menjadi tugas dari Disbudpar Kota Pekanbaru peran serta pihak lain selama ini belum terlalu signifikan fungsinya, sehingga dibutuhkan peran aktif dari berbagai pihak yang terkait dalam pengembangan potensi Wisata Desa Okura yang berbasis wisata alam dan kearifan lokal. Pengembangan Desa Wisata Okura ini membutuhkan kerjasama yang terkonsep, yang secara komprehensif dapat menyentuh berbagai kepentingan, sehingga tidak dibebankan kepada instansi-instansi tertentu saja tetapi lebih menjadi tanggung jawab bersama antar pihak demi terwujudnya destinasi unggulan yang terbaru dan menarik Desa Wisata Okura, peran perusahaan swasta sangat dibutuhkan untuk ikut membangun sarana prasarana yang dibutuhkan oleh wisatawan yang berkunjung di Desa Wisata Okura.

\section{4) Penyusunan Target atau Skala Prioritas dalam usaha Pengembangan Desa Wisata Okura}

Usaha Pengembangan Desa Wisata Okura oleh Dinas Kebudayaan dan Pariwisata Kota Pekanbaru harus mengetahui apa yang menjadi keunggulan Desa Wisata Okura yang nantinya menjadi skala prioritas untuk dipertahankan ataupun basis pengembangan Desa Wisata Okura dan menjadi kegiatan-kegiatan prioritas. 
Prioritas pengembangan pariwisata Desa Wisata Okura dan penyediaan infrastruktur yang dibutuhkan oleh wisatawan belum diketahui kapan akan dicapai, tergantung dana yang tersedia di Pemerintah Kota Pekanbaru. Dana pengelolaan Desa Wisata Okura yang diberikan oleh Pemerintah Kota Pekanbaru melalui Dinas Kebudayaan dan Pariwisata Kota Pekanbaru, belum mampu untuk mengembangkan serta menyediakan infrastruktur yang mendukung Desa Wisata Okura sesuai dengan skala prioritas dan target dari Dinas Kebudayaan dan Pariwisata Kota Pekanbaru.

2. Organizing pengembangan potensi pariwisata di Desa Wisata Okura Kota Pekanbaru Provinsi Riau

\section{1) Tugas dan Fungsi Seksi Promosi Dinas Kebudayaan dan Pariwisata Kota Pekanbaru}

Pembagian kerja pada dinas kebudayaan dan pariwisata kota pekanbaru bertujuan untuk terfokusnya kegiatan demi mencapai tujuan pengembangan yang baik.

2) Tugas dan Fungsi Seksi Sarana dan Prasarana Dinas Kebudayaan dan Pariwisata Kota Pekanbaru

Pengorganisasian pada seksi sarana dan prasarana mempunyai tugas membantu mengembangkan Desa Wisata Okura, salah satunya dengan penyediaan bahan-bahan teknis atau infrastruktur lapangan yang akan memudahkan wisatawan berkunjung di objek wisata Desa Okura.

Kegiatan Promosi Desa Wisata Okura Kota Pekanbaru yang dilaksanakan oleh Seksi Promosi Dinas Kebudayaan dan Pariwisata Kota Pekanbaru tidak berjalan secara maksimal. Program dan penyiapan bahan-bahan promosi wisata Disbudpar lakukan tetapi tidak ada keberlanjutan dikarenakan mengalami hambatan pada pelaksanaan teknis yang disebabkan oleh kurangnya ketersediaan anggaran yang ada, sedangkan anggaran yang dibutuhkan untuk mengembangkan Desa Wisata Okura oleh Pemerintah Kota Pekanbaru cukup banyak. Keterlibatan Pihak Swasta dengan pemerintah tidak terjalin dengan baik karena pihak swasta tidak tertarik untuk ikut mengelola karena kurangnya keuntungan dan jenis pariwisata yang berbasis kearifan lokal tidak menarik bagi pihak swasta. Sehingga Pemerintah Kota Pekanbaru menggunakan biaya seadanya untuk mempromosikan Desa Wisata Okura.

\section{3) Seksi Rekreasi dan Hiburan Dinas Kebudayaan dan Pariwisata Kota Pekanbaru}

Desa Wisata Okura memiliki berbagai potensi wisata unggulan yang sangat baik dikembangkan dan diperkenalkan kepada wisatawan dan pihak yang terkait didalamnya. Pengorganisasian seksi rekreasi dan hiburan Dinas Kebudayaan dan Pariwisata Kota Pekanbaru mempunyai tugas dan fungsi melakukan pelaksanaan penghimpunan dan pengolahan data tempattempat rekreasi dan hiburan sehingga dapat diketahui bahwa di Desa Okura memang benar mempunyai objek wisata unggulan yang berbeda dengan lainnya dan menarik untuk dikembangkan sebagai destinasi wisata yang baru di Kota Pekanbaru.

Seksi Rekreasi dan Hiburan ini melaksanakan tugas dan fungsinya sesuai visi dan misi Dinas Kebudayaan dan Pariwisata Kota Pekanbaru agar Desa Wisata Okura bisa dikenal luas oleh masyarakat lokal dan mancanegara. Namun hambatan yang diperoleh Seksi Rekreasi dan Hiburan Dinas Kebudayaan dan Pariwisata Kota Pekanbaru adalah susahnya mencari pihak ketiga atau penanam modal untuk ikut terlibat dalam mengembangkan Desa Wisata Okura. Seksi Rekreasi dan Hiburan Dinas Kebudayaan dan Pariwisata Kota Pekanbaru hanya mengandalkan Sumberdaya dari masyarakat Desa Wisata Okura dan Pemerintah Kota pekanbaru sendiri. Sehingga promosi dan kegiatan rekreasi, hiburan yang dilaksanakan oleh Dinas Kebudayaan dan Pariwisata Kota Pekanbaru di kemas secara sederhana dan seadanya sehingga terkesan tidak menarik bagi wisatawan. Kurangnya kreativitas masyarakat dan inovasi Dinas Kebudayaan dan Pariwisata Kota Pekanbaru dalam memberikan kemasan Desa Wisata Okura menjadi salah satu penyebab menurunnya jumlah wisatawan lokal dan mancanegara yang berkunjung di Desa Wisata Okura.

3 Actuating pengembangan potensi pariwisata di Desa Wisata Okura Kota Pekanbaru Provinsi Riau.

\section{1) Komunikasi dan Pengarahan Pada Masyarakat Desa Wisata Okura}


Penggerakan yang dilakukan melalui cara komunikasi dan memberikan pengarahan langsung pada masyarakat Desa Wisata Okura yang dilakukan oleh Disbudpar Kota Pekanbaru bertujuan memfokuskan pada peningkatan kemampuan yang dimiliki oleh masyarakat desa, perlu adanya upaya dari pemerintah untuk membantu masyarakatnya berkembangnya dengan adanya komunikasi yang baik dan pengarahan yang tersusun diharapkan mampu memunculkan suatu ide-ide kreatif.

Dinas Kebudayaan dan Pariwisata Kota Pekanbaru sudah melakukan komunikasi dan pengarahan pada masyarakat untuk menjaga khas dan adat istiadat melayu agar meningkatkan kreatifitas dan mempelajari budaya-budaya melayu yang khas serta berlaku ramah terhadap wisatawan yang datang berkunjung. Disbudpar Kota Pekanbaru menginventarisasi langsung ke Desa Okura kemudian mengadakan musyawarah atau diskusi bersama masyarakat, memberikan pengarahan dan membentuk kelompok-kelompok seni budaya lokal masyarakat seperti kelompok seni tari, kelompok olahraga tradisional, kelompok kuliner Desa Okura. Tidak hanya komunikasi dan pengarahan, pelaksanaan teknis sarana dan prasarana di lapangan untuk mendukung peningkatan itu semua juga dibutuhkan.

2) Desa Wisata Okura sudah memiliki legitimasi hukum penetapan sebagai Kawasan Desa Wisata Okura

Ketetapan hukum atau legitimasi hukum sangat diperlukan untuk memberikan kelancaran dalam melaksanakan kegiatan di Desa Okura, melalui proses yang panjang akhirnya diperolehlah legalitas hukum penetapan Okura sebagai Desa Wisata. Ini adalah salah satu bentuk penggerakan yang dilakukan masyarakat Desa Okura dengan Pemerintah Kota Pekanbaru melalui Disbudpar. legalitas hukum yang diberikan Dinas Kebudayaan dan Pariwisata Kota Pekanbaru sangat penting oleh masyarakat Desa Wisata Okura agar bantuan dan pengembangan Desa Wisata Okura berjalan maksimal. Adanya legalitas hukum dalam bentuk keputusan Pemerintah Kota Pekanbaru untuk menetapkan Desa Wisata Okura sebaga Desa Wisata akan meningkatkan kinerja Pemerintah untuk mengembangkan budaya melayu dan kreatifitas masyarakat melayu untuk mempertahankan kearifan lokal sehingga menarik wisatawan untuk berkunjung ke Desa Wisata Okura.

\section{3) Pengelolaan Desa Wisata Okura menjaga, melestarikan dan meningkatkan kualitas Sumber} daya yang ada

Desa wisata Okura sebagai destinasi baru wisata Kota Pekanbaru tentu perlu pengelolaaan dan pengembangan yang baik, melalui pihak berwenang mengelolanya yakni Disbudpar Kota Pekanbaru bekerja sama dengan masyarakat di Desa Okura untuk membantu mengelola dan mengembangkan Desa Wisata ini agar memberikan dampak sesuai dengan tujuan yang ditetapkan.

Dinas Kebudayaan dan Pariwisata Kota Pekanbaru memberikan pengarahan kepada masyarakat di Desa Wisata Okura agar terus melestarikan Kebudayaan melayu dan meningkatkan kualitas sumberdaya dengan memberikan pelatihan kepada masyarakat seperti pelatihan dan praktek pengoperasian software arab melayu digital, pelatihan pelayanan publik yang baik dan ramah terhadap wisatawan yang datang berkunjung. Pengarahan dan pelatihan yang diberikan oleh Dinas Kebudayaan dan Pariwisata Kota Pekanbaru dalam memberikan pengarahan dan pelatihan masih apa adanya karena belum didukung dengan sarana dan prasarana, kemudian tenaga teknis ahli yang mendukung hasil pengarahan dan pelatihan yang diberikan oleh Dinas Kebudayaan dan Pariwisa Kota Pekanbaru.

Jadi dalam melakukan pengelolaan terhadap sumber daya yang ada di Desa Wisata Okura perlu diupayakan sebaik mungkin supaya tujuan yang hendak dicapai dapat terlaksana sebagaimana mestinya. Terlepas dari itu semua bantuan dari berbagai pihak dalam proses pengelolaan ini pihak swasta, para penggiat wisata profesional dan para ahli dalam bidang manajemen diharapkan ikut terlibat aktif dan langsung didalam proses pengelolaan ini, melalui komunikasi yang baik dan daya tarik objek wisata Desa Okura ini sehingga bantuan yang diharapkan dapat hadir di tengah proses pengembangan Desa Wisata Okura ini.

\section{Pengendalian pengembangan potensi pariwisata di Desa Wisata Okura Kota Pekanbaru Provinsi Riau}


Actuating atau penggerakan merupakan tahapan yang harus dilaksanakan oleh Disbudpar Kota Pekanbaru selaku yang berwenang menangani pengembangan di bidang pariwisata, salah satu wujud tindakan nyata atau aktualisasinya adalah merumuskan kegiatan-kegiatan melalui pemikiran-pemikiran yang ada pada anggota Disbudpar Kota Pekanbaru dengan keahlian dibidangnya masing-masing yang merupakan kelanjutan dari proses perencanaan dan pengorganisasian, hasil dari kelanjutan tersebut akan di aktualisasikan pada Desa Wisata Okura.

Pengendalian dimaksudkan untuk melihat apakah kegiatan organisasi sudah sesuai dengan recana sebelumnya. Fungsi pengendalian mencakup empat kegiatan, yakni (1) menentukan standar prestasi, (2) mengukur prestasi yang telah dicapai selama ini, (3) membandingkan prestasi yang telah dicapai dengan standar prestasi, dan (4) melakukan perbaikan jika terdapat penyimpangan dari standar prestasi yang telah ditetapkan. (Amirullah, dkk 2004:13)

Pengendalian (controlling), yakni meneliti dan mengawasi agar semua tugas dilakukan dengan baik dan sesuai dengan peraturan yang ada atau sesuai dengan deskripsi kerja masing-masing personal. Pengawasan yang lebih baik adalah pengawasan dalam arti pembinaan dan pemberdayaan, sehingga dengan menjalankan fungsi pengawasan, seluruh personalia organisasi memiliki rasa pengabdian, komitmen, dan loyalitas yang tinggi pada pekerjaan dan organisasi tempatnya bekerja. Begitu juga pengawasan dan pengendalian yang dilakukan oleh Disbudpar Kota Pekanbaru dalam mengawasi terlaksananya pengembangan yang baik pada Desa Wisata Okura, berikut adalah sub fenomena untuk menjelaskan pengawasan dan pengendalian yang dilakukan :

1) Pengendalian pelestarian pariwisata yang mengandung nilai budaya melayu di Desa Wisata Okura oleh Dinas Kebudayaan dan Pariwisata Kota Pekanbaru.

Potensi pariwisata yang ada di Desa Wisata Okura haruslah dilestarikan oleh karena itu pihak Disbudpar Kota Pekanbaru mendeteksi potensi wisata apa sajakah yang harus di lakukan pelestarian yang kemudian melakukan pengendalian agar wisata yang ditetapkan sesuai dengan nilainilai kepariwisataan yang mengandung nilai budaya melayu berbasis kearifan lokal. Proses pengendalian pada sebuah objek wisata seperti Desa Wisata Okura yang berbasis kearifan lokal harus berdasarkan nilai-nilai kepariwisataan dalam bentuk pelestarian budaya dan adat istiadat melayu yang ada di Desa Wisata Okura. Pengendalian pelestarian yang dilakukan oleh Dinas Kebudayaan dan Pariwisata Kota Pekanbaru belum banyak dilakukan terlihat kondisi objek wisata yang kurang terawat dengan baik. Hal ini berdampak langsung kepada proses kemajuan pengembangan Desa Wisata Okura, dengan ada adanya pengendalian pelestarian objek wisata yang ada di Desa Okura tentunya akan dapat mendatangkan daya tarik bagi wisatawan yang akan berkunjung.

Dinas Kebudayaan dan Pariwisata Kota Pekanbaru melaksanakan pengendalian pelestarian melalui pokdarwis dan ketua Lembaga Keswadayaan Masyarakat Desa Okura untuk mengetahui permasalahan yang ada dalam lingkungan masyarakat yang berkaitan dengan pengembangan Desa Wisata Okura dan memberikan laporan kepada Dinas Kebudayaan dan Pariwisata Kota Pekanbaru agar turun lapangan dan mengambil tindakan atau upaya terkait pengembangan Desa Wisata Okura yang berbasis kearifan lokal.

2) Usaha yang dilakukan dalam mengawasi kearifan budaya melayu, pemanfaatan sumber daya, serta usaha pengendalian untuk meningkatkan kualitas sumber daya Desa Wisata Okura.

Kegiatan-kegiatan yang dilaksanakan dalam proses manajemen tidak akan membawa hasil yang berarti kalau tidak segera diikuti dengan usaha pengendalian yang dilakukan. Dengan demikian, bisa kita katakan bahwa fungsi ini memiliki kedudukan penting dalam kegiatan manajemen karena dengan pengendalian yang baik atau efektif merupakan jaminan bahwa tujuan yang telah ditetapkan dalam rencana akan tercapai. Usaha yang dilakukan Disbudpar Kota Pekanbaru senantiasa melakukan koordinasi dengan kelompok perwakilan peduli wisata yang ada di Desa Okura namun Disbudpar Kota Pekanbaru belum menetapkan standar dan metode untuk mengukur tingkat keberhasilan pengembangan yang dilakukan sehingga belum dapat menjamin bahwa sumber daya yang ada di Desa Okura digunakan secara lebih efektif dan efisien. Usaha yang dilakukan selama ini hanya bentuk swadaya masyarakat saja, permasalahan infrastruktur atau sumber 
daya dilapangan kemudian dilaporkan masyarakat kepada Lembaga Keswadayaan Masyakat Okura yang nantinya akan diteruskan kepada Disbudpar Kota Pekanbaru.

Dinas Kebudayaan dan Pariwisata Kota Pekanbaru, telah menyelenggarakan fungsi pengendalian, dengan berkoordinasi bersama Lembaga Keswadayaan Masyarakat Desa Okura dan Kelompok Peduli Wisata agar memantau dan mengawasi pelaksanaan pengembangan Desa Wisata Okura. Fungsi pengendalian harus ada tindak lanjut dari Dinas Kebudayaan dan Pariwisata Kota Pekanbaru agar permasalahan yang dihadapai dilapangan dalam pengembangan Desa Wisata Okura. Masih adanya permasalahan yang terjadi dilapangan seperti kurangnya sarana dan prasarana yang dirasakan oleh masyarakat diindikasikan pengendalian yang dilakukan oleh Dinas Kebudayaan dan Pariwisata Kota Pekanbaru tidak berjalan optimal, karena tidak adanya tindak lanjut untuk memecahkan permasalahan yang ada di Desa Wisata Okura.

\section{KESIMPULAN}

Fungsi Perencanaan yang dilakukan oleh Disbudpar Kota Pekanbaru dalam mengelola dan mengembangkan Desa Wisata Okura belum berjalan dengan optimal dan masih perlu ada perbaikan. Perencanaan pengembangan di Desa Okura telah dilakukan namun hanya berupa event-event tertentu saja, belum berupa program keberlanjutan sehingga berdampak pada keberlanjutan pengembangan desa itu sendiri dan kurang berkembangnya potensi pariwisata yang ada di Kota Pekanbaru.

Fungsi Pengorganisasian yang dilakukan melalui seksi yang mewakili fokus program kerja masingmasing, terdiri dari seksi promosi pariwisata, seksi sarana dan prasarana dan seksi rekreasi hiburan. Masingmasing seksi tersebut mengalami hambatan pengelolaan dan pengembangan salah satunya anggaran yang belum memadai dan kondisi pengetahuan masyarakat yang masih rendah.

Fungsi Penggerakan telah dilakukan oleh Disbudpar Kota Pekanbaru dengan cara berkomunikasi dan memberikan arahan langsung kepada masyarakat di Desa Okura, bekerjasama dan memberikan informasi bahwa Desa Okura akan dikembangkan menjadi destinasi desa wisata berbasis kearifan lokal di Kota Pekanbaru setelah itu Disbudpar menetapkan dengan mengeluarkan ketetapan hukum yakni Keputusan Kepala Dinas Kebudayaan dan Pariwisata Kota Pekanbaru tentang penetapan Desa Okura sebagai kawasan desa wisata. Namun belum berjalan optimal pada saat Dinas Kebudayaan dan Pariwisata Kota Pekanbaru memberikan pelatihan dan penyuluhan kepada masyarakat untuk menjaga dan melestarikan kebudayaan melayu. Kurangnya ketersediaan sarana dan prasarana, tenaga ahli dan kondisi pengetahuan masyarakat yang rendah menjadi salah satu faktor penghambat pengelolaan dan pelestarian kebudayaan melayu di Desa Wisata Okura.

Fungsi Pengawasan atau Pengendalian diketahui bahwa Dinas Kebudayaan dan Pariwisata Kota Pekanbaru, telah menyelenggarakan fungsi pengawasan dan pengendalian, dengan berkordinasi bersama Lembaga Keswadayaan Masyarakat Desa Okura dan Kelompok Peduli Wisata agar memantau dan mengawasi pelaksanaan pengembangan Desa Wisata Okura. Namun yang menjadi permasalahan belum optimalnya terletak pada konsistensi atau jadwal berkala pengawasan dan pengendaliannya harus berfokus pada kepentingan-kepentingan tertentu seperti adanya event-event tertentu yang sifatnya hanya sementara, tentulah hal ini yang harus menjadi perhatian Disbudpar sebagai pengawas dan pengendali pengembangan Desa Wisata Okura untuk terus berkelanjutan dan meningkatkan keseriusan untuk menjaga kesinergisan pengembangan Desa Wisata tidak hanya adanya kepentingan tertentu apapun.

\section{Saran}

Penelitian mengenai Manajemen pengembangan potensi pariwisata daerah di Desa Wisata Okura Kota Pekanbaru Provinsi Riau telah dilakukan secara keseluruhan oleh Dinas Kebudayaan dan Pariwisata Kota Pekanbaru namun berdasarkan penilaian indikator manajemen menurut George Robert Terry yakni Planning, Organizing, Actuating dan Controlling masih belum optimal dilaksanakan. Berikut adalah beberapa saran dari peneliti terhadap manajemen Desa Wisata Okura yang dapat digunakan untuk memperbaiki, mengoptimalkan pengelolaan yang ada dan mengembangkan Desa Wisata Okura:

a. Disbudpar Kota Pekanbaru harus melakukan perencanaan yang optimal dalam mengelola dan mengembangkan Desa Wisata Okura dengan membuat suatu program yang bekerlanjutan sehingga 
berdampak pada keberlanjutan pengembangan desa itu sendiri, membuat target jangka pendek, menengah dan jangka panjang sebagai pedoman atau tolak ukur target yang akan dicapai

b. Dalam proses pengorganisasian Disbudpar Kota Pekanbaru perlu membuat standar operasional prosedur (SOP) dalam kegiatan pengembangan Desa Wisata Okura dan fokus melaksanakan Tupoksi sesuai dengan bidang pengembangan pariwisata yang dilakukan sehingga nantinya dapat dinilai kemajuan prestasinya sesuai dengan standar yang telah ditetapkan.

c. Fungsi penggerakan yang dilakukan Disbudpar Kota Pekanbaru jangan hanya melakukan koordinasi dibidang pemantauan potensi objek wisata, sarana dan prasarana yang tersedia apa saja melainkan juga fokus melakukan pemberdayaan sumber daya manusia yang ada di Desa Wisata Okura dengan memberikan berbagai pembinaan dan pelatihan, mendatang tenaga ahli untuk memberikan pengetahuan khusus pada masyarakat di Desa Okura bagaimana melestarikan sumber daya yang ada dan mengembangkan potensi wisata yang tersedia dan terakhir peranan dari para pemangku kebijakan atau stakeholders dan pihak yang terkait lainnya agar melakukan pelaksanaan program atau kebijakan yang terintegrrasi dan berkesinambungan.

d. Pada proses pengawasan yang dilakukan seharusnya lebih ditingkatkan konsistensi dan membuat jadwal berkala pengawasan dan pengendaliannya, yang selama ini masih terfokus pada pengawasan kepentingan-kepentingan tertentu seperti adanya event-event wisata tertentu yang sifatnya hanya sementara.

e. Menyediakan dana khusus untuk fokus melakukan pengembangan di Desa Wisata Okura sebab Kota Pekanbaru secara khusus bukanlah kota wisata seperti kota-kota besar lainnya di Indonesia. Dengan adanya pengembangan Desa Wisata ini diharapkan bisa menjawab minimnya tempat wisata alam dan mengurangi tingkat stress dan kejenuhan para penduduknya. Pemerintah Kota Pekanbaru melalui Disbudpar harus lebih kreatif dalam mendapatkan dukungan, harus lebih mampu membuat mereka tertarik dan harus lebih meningkatkan kerjasama dengan pihak swasta atau pihak yang kiranya dapat membantu permasalahan pengembangan Desa Wisata Okura seperti masalah Infrastruktur wisata, Promosi wisata, pembinaan SDM di Desa Wisata Okura.

\section{DAFTAR PUSTAKA}

Amirullah, Haris Budiyono. 2004. Pengantar Manajemen. Edisi Kedua. Yogyakarta. Graha ilmu.

Athoillah, Anton. 2010. Dasar-dasar Manajemen. Cetakan I. Bandung. Pustaka Setia, cv.

Handoko, Hani. 2003. Manajemen edisi 2. Yogyakarta. BPFE-Yogyakarta.

Kencana Syafiie, Inu. 2010. Ilmu Administrasi Publik. Jakarta. Rineka Cipta, pt.

Moleong, Lexi, Prof. Dr., MA. (2009). Metode Penelitian Kualitatif. Bandung. Remaja Rosdakarya, pt.

Miles, Huberman, Saldana. (2014). Qualitative Data Analysis: a methods source book Edition 3. United States of America: SAGE Publications, Inc.

Mulyadi, Deddy. 2016. Studi Kebijakan Publik dan Pelayanan Publik. Cetakan ke-2 Bandung. Alfabeta, cv.

Pasolong, Harbani. 2008. Teori Administrasi Publik. Cetakan ke-1. Bandung: Alfabeta, cv.

Pasolong, Harbani. 2011. Teori Administrasi Publik; Cetakkan Ketiga. Bandung Alfabeta, cv.

Pitana, I Gde dan I Ketut Surya Diarta. 2009. Pengantar Ilmu Pariwisata. Yogyakarta. Andi Offset.

Santosa, Pandji. 2008. Administrasi Publik, Teori dan Aplikasi Good Governance, cetakan ke-1. Bandung. Refika Aditama, pt.

Undang-undang Nomor 10 Tahun 2009 Tentang Kepariwisataan.

Instruksi Presiden Republik Indonesia Nomor 9 Tahun 1969 Tentang Pedoman Pembinaan Pengembangan Kepariwisataan Nasional.

Peraturan Daerah Nomor 13 Tahun 2000 Tentang Promosi Pariwisata Daerah Kota Pekanbaru. 